\title{
Characteristics of Child Labour and Their Health Problems: Findings from Rural Community of India
}

\author{
Sourav Mondal' ${ }^{1}$ Koustuv Dalal2*, Dilip Kumar Sahoo' ${ }^{1}$, Animesh Biswas ${ }^{3}$ \\ ${ }^{1}$ Dr. Kanailal Bhattacharyya College, Howrah, India \\ ${ }^{2}$ School of Health Sciences, Örebro University, Örebro, Sweden \\ ${ }^{3}$ Centre for Injury Prevention and Research, Dhaka, Bangladesh \\ Email: "koustuv2010@hotmail.com
}

Received 12 May 2016; accepted 11 July 2016; published 14 July 2016

Copyright (C) 2016 by authors and Scientific Research Publishing Inc.

This work is licensed under the Creative Commons Attribution International License (CC BY). http://creativecommons.org/licenses/by/4.0/

\section{(c) (i) Open Access}

\begin{abstract}
Background: Child labour is a big problem. Studies have indicated several problems of child labour. However, few studies have indicated the characteristics of child labour rural India. Objectives: This study has explored characteristics of child labour and their families in the rural community of eastern India and also identified their health problems. Methods: A cross-sectional study was designed to explore their characteristics in purposively selected areas in rural Howrah, India. Frequency table and bar-diagrams were used. Results: The study identified $\mathbf{7 2 \%}$ boys and $28 \%$ girls as child labour. Majority of the children (67.9\%) were labour because they wanted to help their parents. In $8.9 \%$ cases, they were forced to work by their parents. In $5.4 \%$ cases, they were orphans. Majority of the children were not satisfied $(\mathbf{7 8 . 6 \% )}$ with their job place and job status. Conclusions: Child labourers are not satisfied with their job. Their money is used in family. Parents are illiterate. Lack of effective education system and availability of functional schools are both causes and consequences of child labour. Due to illiteracy, working conditions for these children get worse as they are not even aware of the occupational benefits.
\end{abstract}

\section{Keywords}

Child Labour, Characteristics, Parents, Illiteracy, Rural, India

\section{Introduction}

Child labour considered as one of the major public health issue globally [1]. According to ILO, a total of 250

${ }^{*}$ Corresponding author.

How to cite this paper: Mondal, S., Dalal, K., Sahoo, D.K. and Biswas, A. (2016) Characteristics of Child Labour and Their Health Problems: Findings from Rural Community of India. Health, 8, 931-936.

http://dx.doi.org/10.4236/health.2016.810096 
millions children are working as labour in the world. Asia comprises highest 153 millions whereas in Africa region, child labour is around 80 millions [2]. It also stated that near to $50 \%$ of the global child laborers are engaged in hazardous works [3]. Moreover, in the Asian and pacific regions, majority of the children are working in agricultural sector [4]. One study illustrated context of Asia and shown the distribution of child labour among the age group of 10 - 14 years in Bangladesh is 30.1; Pakistan is 17.7; China is 11.6 and in India is 14.4 [5]. Majority of the children are working among the child laborer rather going to school. They work in factories and in fields, sew footballs and t-shirts, and pick cotton and cocoa. They mine and dig, serve in homes and fight in wars. They are trapped in poverty with little hope of escape [6]. However, corporate code of child labour should be specific, strictly implemented and monitored for restraining under age child workers [7]. Socio economic condition and poverty are contributed as key factors to contribute child labour [8]. It is also identified that economy is a development trap where child labour is abundant [9]. Main factors associated with child labor are poverty, level of development, income inequality, school enrolment, parent's education, dominance of agricultural work and age structure [10]. It has been estimated that boys tend to be more involved in employment than girls. The employment rate was 18.1 per cent for boys compared to 15.2 per cent for girls [11]. Though restrictions on child labor exist in most nations, many children still do work. This vulnerable state leaves them prone to exploitation.

There is a strong negative physical and psychosocial health impact of child labour upon child health. Literature demonstrates that child labour frequently experiences work related injuries and health problems [12]. The health related problems of the child labour are very high in the developing countries in absent of proper knowledge and preventive actions.

The International Labour Office reports that children work the longest hours and are the worst paid of all laborers [13]. There are two reasons to examine the situation of working children in the developed world. First, by no means have all the historical problems associated with child labour solved in these countries. Workers under the age of 18 play an essential economic role in most of the developed world, and no country has been successful in protecting them from physical, social, or economic harm. The second reason is that the record of the developed countries provides important evidence for hypotheses that guide policy in the developing world [14]. In Bangladesh, it is found that subsidy increases' schooling by far more than it reduced child labour, but its actual effect on child labour was not visualized [15]. In India, there are 17 million child laborers of organized sectors contributing up to $20 \%$ of the Indian Gross Domestic Product (GDP) whereas, another 46 million children engaged in unorganized sectors. It is also stated that child labourers of organized sectors are economically beneficial as they are $80 \%$ cheaper than members of the adult labour force [16]. However, characteristics of child labour and their health problems are still not clearly known in rural India. This study explored characteristics of child labour and their families and their health issues in the rural community of eastern India.

\section{Method}

A cross sectional study was conducted in where quantitative method was used. A pre-tested questionnaire was used to collect information on child labour.

Data collection was conducted during September 2013 to August 2014. The study was conducted in two purposively selected administrative blocks (Amta and Sankrail) in Howrah district India. Necessary administrative permission was sought for selecting the villages and eventually the households with child labour. After discussion with the elected people's representative in the administration, we have identified three villages from Amta block and two villages from Sankrail block.

Then two senior researchers visited the village chief with duly authorized permission from higher authority. The village chief had identified the households with child labour. We have considered the age group up to 17 years for considering the child labour as per ILO guideline [5]. A total number of 127 children were indetified. Among them, 89 were boys and rest of them were girls. The researchers then visited the identified households and sought permission from the household head for discussion of the study objective, in presence of the village chief. All visited household have provided permission to ask questions to the child labour. If there were more than one child labour in the household the researcher had randomly selected one respondent. We found four households with two child labour in each house. Moreover, 11 children were outside the village. Finally, we recruited 112 children for the study. Then the researchers had informed the respondent girls or boys about the study objectives and their willingness to participate in the study. Surprisingly, all of the selected child labours 
were more than willing to response and opined to disclose their feelings and problems.

Due to lack of literacy of the parents/guardians, the study has sought verbal consent of the parent/guardian of the child labour. Necessary permission was obtained from the administrative authorities.

Operation definition for health problem was sought for this study. Children were asked about their health problems in past six months from the date of data collection. It was self-reported and health problems (illness) were recorded if the child seek any treatment for his/her health problem or was ill for at least three days or unable to do daily routine activities for three days or both. The identity of the child labourers had been under strict confidentiality. Frequency table and bar diagrams were used to represent the statistics. Open ended answers were dealt using thematic text analyses.

\section{Results}

Among the 112 children interviewed, 81 were boys and 31 were girls. Minimum age we found was 10 years. Majority of the children (59\%) are in the age group $16-17$ years, while $12.5 \%$ of children were at age group between 10 - 12 years.

The mean age of the mothers of the child labor is $35.6 \pm 6.2$ years with a range between 24 and 52 years. The mean age of the father was $45.5 \pm 6.4$ years ranging between 33 to 57 years. A large number of mother (34\%) and father (47\%) were found illiterate, while $40.2 \%$ mothers and $35 \%$ father studied up to primary level (Figure 1).

Social characteristics of the children had shown that majority of the child labourers had mobile phone (87.4\%), electricity (82\%) and clock (79.3\%) in their home. However, only $8.1 \%$ the child labour had a piece of agricultural land to use (Figure 2).

It had been explored that majority of the children (67.9\%) were labour because they wanted to help their parents. In $8.9 \%$ cases, they were forced to work by their parents. In $5.4 \%$ cases they were providing labour for their survival as they were orphans (Table 1 ).

Majority (80.4\%) of the families had faced difficulties to earn money for minimum level of survival, which eventually pushed the children to become child labour. The study also revealed that in $71.4 \%$ cases, they had a social problem in the neighborhood that forced them to become child labour. It had also found that in majority of the cases $(75.9 \%)$ the money earned by the children used by their parents. Majority of the children were not satisfied (78.6\%) with their job place and job status.

Most of the child labourers had told that they have some health problems. Over $71 \%$ of the children reported health problems $(\mathrm{n}=80)$. Stress and depression was found highest among other health problems $(21.3 \%)$. A large number of the children suffered from back pain (16.3\%), whereas injuries like burn, cut, eye and machine injury were common. However, around $19 \%$ of them had others different type of health problems like fever, discomforts, muscle crump, sprain, common cold, fever etc. (Figure 3).

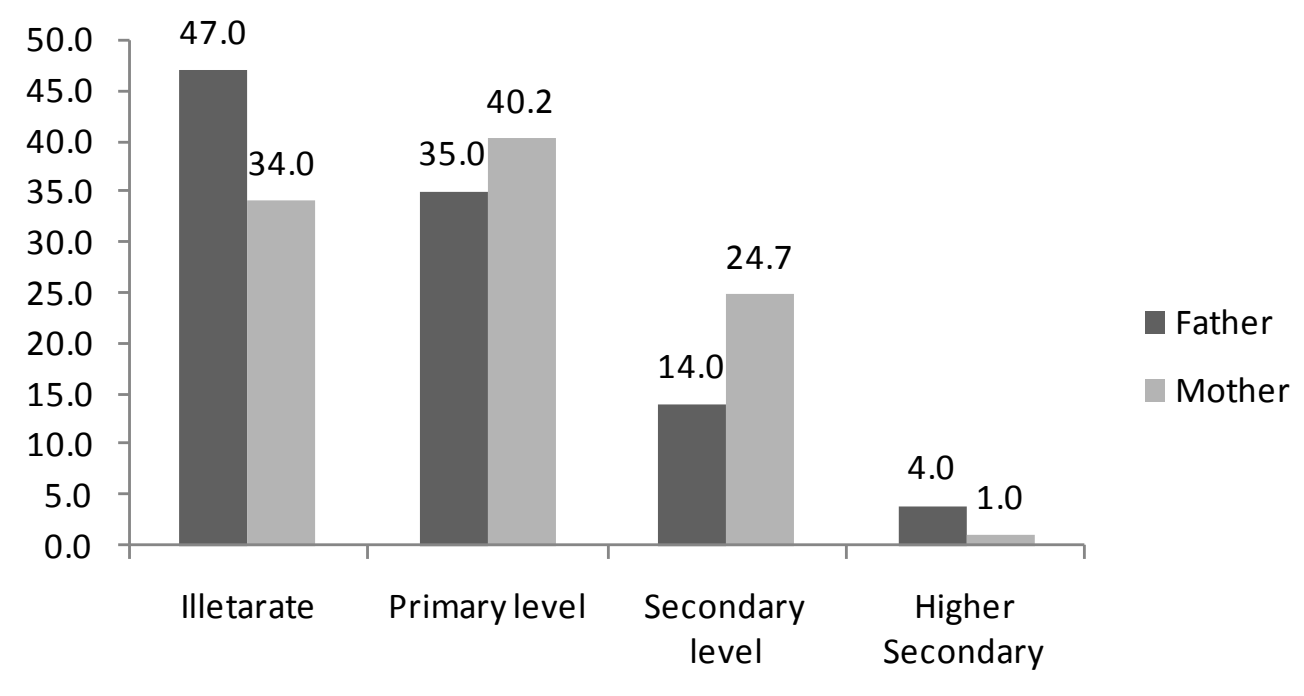

Figure 1. Educational level of parents of child labour. 


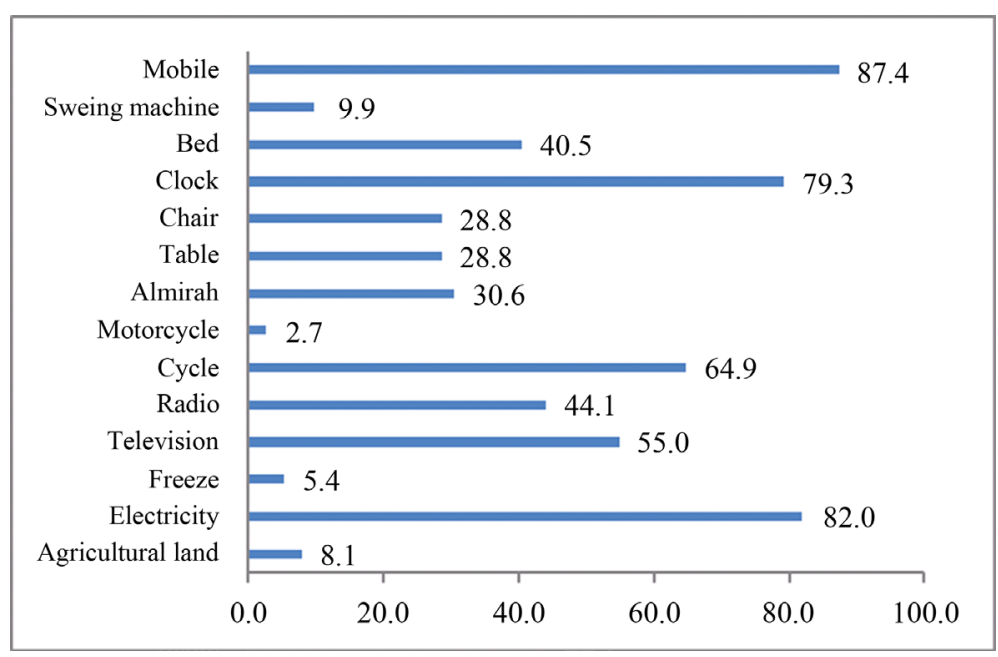

Figure 2. Assets status of child labour at home.

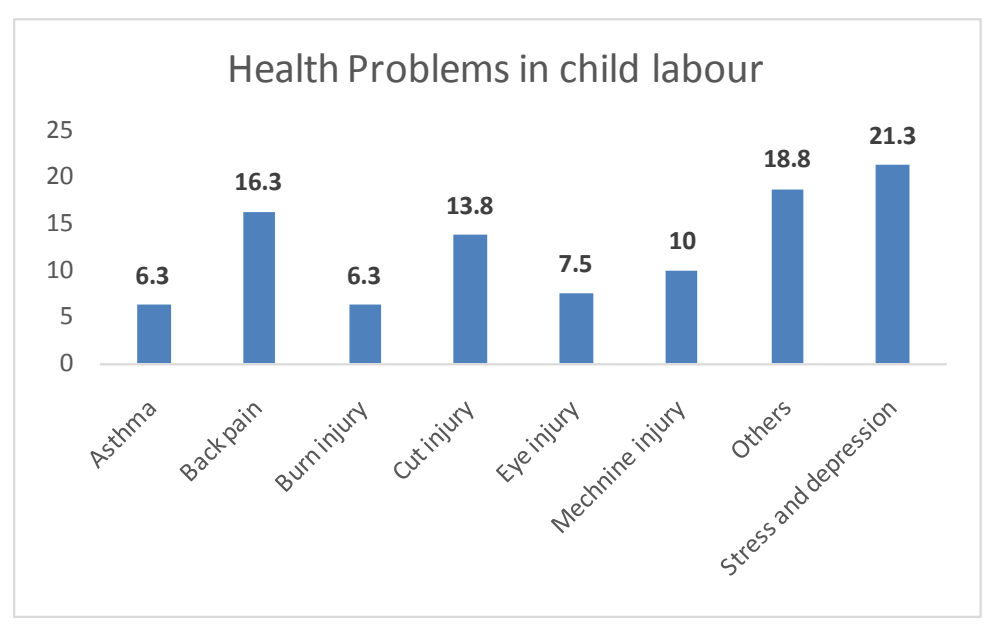

Figure 3. Health problems in child labour.

Table 1. Reasons for being child.

\begin{tabular}{ccc}
\hline Over all & Number & Percentage (\%) \\
\hline Financial help to parents & 76 & 67.9 \\
Forced to work & 10 & 8.9 \\
Illiterate parents & 4 & 3.6 \\
Financial help to mother & 4 & 3.6 \\
Orphan & 6 & 5.4 \\
Self-assigned & 9 & 8.0 \\
Study finance & 1 & 0.9 \\
Not response & 2 & 1.8 \\
\hline
\end{tabular}

\section{Discussion}

The study explored that boy labourers were higher than girls and they were engaged in doing labour job because of needs of their families. Low socioeconomic status including inadequate level of education forced them to become child labour. Therefore, major part of the money earned by the child labour was spent in the families. Al- 
though the children worked due to family and social problems, they were not satisfied by their own income and job nature. One of the studies mentions that children are most vulnerable in poor families because the poverty transmits one generation to another generation; moreover, it has been also associated with poverty and illiteracy [16] [17]. In this study, a large number of parents were illiterate. A study in Kolkata, India, also found child labour was higher in illiterate parents [18]. One in every seven children is child labour globally. About 218 million children engaged labour work at factory and field which included sewing football and t-shirt, picking cotton, mining, digging and serving at home instead of education [19]. The prevalence of mental disorders was noted to be as high as $20.1 \%$ compared with $12.5 \%$ in the general population [20]. Child labourers in Indian organized sectors are economically beneficial as they are $80 \%$ cheaper than members of the adult [12]. Economic and policies development is necessary to eliminate child labour [21]. It is interesting to note from the current study that almost four in every five child labourers are unsatisfied.

It also shows that children can earn up to one third of the total family income [22], whereas, children work for less payment without absenteeism, unionism and without demanding any overtime payments [16] [23]. A study in Pakistan states that poverty has been identified as the root cause of child labour in many studies [24]. Another study mentions that child labour is an economic burden for many households, especially poor households in developing countries [25]. Other study describes that the lack of effective education system and availability of functional schools is the cause and the consequence of child labour. Lack of effective education system and availability of functional schools is the cause and the consequence of child labour. Due to illiteracy, working conditions for these children get worse as they are not even aware of the occupational benefits [1]. In this study, poverty is found to be a key challenge which pushes the children to become child labour. This has shown that benefit of doing child labour is found to be more beneficial for the parents than going to school. That has been reflected in other studies [25]. The study shows their dissatisfaction in doing child labour in majority of the cases, which has a negative impact on the physiological and psychological levels of the children which have effects on mental health [26] [27]. Previous study from Bangladesh has indicated that child labourers are vulnerable to injuries, illness and death [12]. However, the current study has specifically indicated that child labour has different physical and mental health problems along with injuries.

Further study is warranted in this regard to explore health and other effects of child labour. The government of India already has taken certain initiative to control of child labour [28] that needs to be strengthened, especially in the west Bengal, India. Moreover, the study also explores that education is most important part of development which needs to be considered to stop child labour.

\section{Conflict of Interest}

Declared none.

\section{References}

[1] Gulzar, S.A., Vertejee, S. and Pirani, L. (2009) Special Communication Child Labour: A Public Health Issue. Determinants of Child Labour, 59, 778-781.

[2] ILO (1999) Facts and Figures on Child Labour. International Labour Organization, Geneva. http://info.worldbank.org/etools/docs/library/237384/toolkitfr/pdf/facts.pdf

[3] ILO (2006) The End of Child Labour: Within reach. International Labour Organization, Geneva.

[4] ILO (2010) Accelerating Action against Child Labour. International Labour Organization, Geneva.

[5] ILO (2015) World Report on Child Labour. International Labour Organization, Geneva.

[6] UNICEF (2015) Fact Sheet: Child Labour. Cited on 1 December 2015. http://www.unicef.org/protection/files/child_labour.pdf

[7] Kolk, A. and Tulder, R.V. (2002) The Effectiveness of Self-Regulation: Corporate Codes of Conduct and Child Labour. European Management Journal, 20, 260-271. http://dx.doi.org/10.1016/S0263-2373(02)00043-9

[8] Ali, M., Shahab, S., Ushijima, H. and de Muynck, A. (2004) Street Children in Pakistan: A Situational Analysis of Social Conditions and Nutritional Status. Social Science \& Medicine, England, 59, 1707-1717. http://dx.doi.org/10.1016/j.socscimed.2004.01.031

[9] Hazan, M. and Berdugo, B. (2012) Child Labour, Fertility, and Economic Growth. The Economic Journal, 112, 810828. http://dx.doi.org/10.1111/1468-0297.00066

[10] Ahmed, I. (1999) Getting Rid of Child Labour. Economic and Political Weekly, 34, 1815-1822. 
[11] ILO (2012) Global Child Labour Trends 2008 to 2012. International Labour Organization, Geneva.

[12] Dalal, K., Rahman, F., Gifford, M. and Rahman A. (2015) The Magnitude of Injury Problems among Child Labourers in a Rural Community of Bangladesh: Findings from an Injury Surveillance System. International Health.

[13] Siddiqi, A. and Patrinos, H.A. (2013) Child Labor: Issues, Causes, and Interventions. Human Capital Development and Operational Policy, 14.

[14] Dorman, P. (2001) Child Labour in the Developed Economies. International Labour Organization, Geneva.

[15] Ravallion, M. and Wodon, Q. (2000) Does Child Labour Displace Schooling? Evidence on Behavioural Responses to an Enrollment Subsidy, 110, 158-175. http://dx.doi.org/10.1111/1468-0297.00527

[16] Dalal, K. (2008) Causes and Consequences of Violence against Child Labour and Women in Developing Countries. Karolinska Institutet, Stockholm.

[17] Lieten, G.K., Weekly, P., Url, S., Count, P. and Viewing, L. (2015) Children, Work and Education-I: General Parameters. Economic and Political Weekly, 35, 2037-2043

[18] Hospital, I., Unit, B.A., Dumm D., Dum, D. and Bengal, W (2008) Whole Time Domestic Child Labor in Metropolitan City of Kolkata. Indian Pediatrics, 45, 579-582.

[19] Sinha, M.S. (2007) Child Labour Exists because We Allow It to Exist. Concern Worldwide. https://www.concern.net/sites/default/files/media/page/concern_child_labour_resource.pdf

[20] Fekadu, D., Alem, A. and Hagglof, B. (2006) The Prevalence of Mental Health Problems in Ethiopian Child Laborers. Journal of Child Psychology and Psychiatry, and Allied Disciplines, 47, 954-959. http://dx.doi.org/10.1111/j.1469-7610.2006.01617.x

[21] Swinnerton, K.A. and Rogers, C.A. (1999) The Economics of Child Labor: Comment. American Economic Review, 89, 1382-1385. http://dx.doi.org/10.1257/aer.89.5.1382

[22] Jejeebhoy, J. (1993) Family Size, Outcomes for Children, and Gender Disparities: The Case of Rural Maharashtra. Proceedings of a Population Council Seminar, New York, 9-10 June 1992, 445-479.

[23] Aggarwal, S.C., Weekly, P., Url, S., Count, P. and Viewing, L. (2015) Child Labour and Household Characteristics in Selected States: Estimates from NSS 55th Round. The Developing Economies, 44, 440-464.

[24] Nafees, A.A., Khan, K.S., Fatmi, Z. and Aslam, M. (2016) Situation Analysis of Child Labour in Karachi, Pakistan: A Qualitative Study. Journal of the Pakistan Medical Association, 62, 1075-1082.

[25] Hesketh, T., Gamlin, J. and Woodhead, M. (2006) Policy in Child Labour. Archives of Disease in Childhood, 91, 721723. http://dx.doi.org/10.1136/adc.2006.096263

[26] Scanlon, T., Prior, V., Lamaro, M.L., Lynch, M.A. and Scanlon, F. (2002) Child Labour. BMJ, 325, 401-403. http://dx.doi.org/10.1136/bmj.325.7361.401

[27] Parker, D. (1997) The Health Effects of Child Labour. Lancet, 350, 1395-1396. http://dx.doi.org/10.1016/S0140-6736(05)65169-0

[28] Srivastava, K. (2011) Child Labour Issues and Challenges. Industrial Psychiatry Journal, 20, 1-3. http://www.ncbi.nlm.nih.gov/pmc/articles/PMC3425238/ 


\section{Submit or recommend next manuscript to SCIRP and we will provide best service for you:}

Accepting pre-submission inquiries through Email, Facebook, LinkedIn, Twitter, etc.

A wide selection of journals (inclusive of 9 subjects, more than 200 journals)

Providing 24-hour high-quality service

User-friendly online submission system

Fair and swift peer-review system

Efficient typesetting and proofreading procedure

Display of the result of downloads and visits, as well as the number of cited articles

Maximum dissemination of your research work

Submit your manuscript at: http://papersubmission.scirp.org/ 